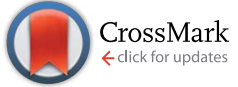

Cite this: RSC Adv., 2017, 7, 3214

Received 21st October 2016 Accepted 15th December 2016

DOI: $10.1039 / \mathrm{c} 6 \mathrm{ra} 25595 \mathrm{~g}$

www.rsc.org/advances

\title{
Solvent-free Knoevenagel reaction catalysed by reusable pyrrolidinium base protic ionic liquids (PyrrlLs): synthesis of long-chain alkylidenes $\uparrow$
}

\author{
R. C. M. Alves Sobrinho, ${ }^{a}$ P. M. de Oliveira, ${ }^{a}$ C. R. Montes D'Oca, ${ }^{a}$ D. Russowsky ${ }^{b}$ \\ and M. G. Montes D'Oca*a
}

In this work, an efficient and reusable pyrrolidinium ionic liquid (PyrrlL) catalysis system was developed and used in a Knoevenagel condensation reaction of long-chain aldehydes with several 1,3-dicarbonyl compounds. The Knoevenagel condensation promoted by the PyrrlLs proceeded smoothly and cleanly in solvent-free conditions, yielding good quantities of the condensation products, long-chain alkylidenes. Moreover, this catalysis system was recyclable at least four times, and no significant loss of activity was observed. This protocol has notable advantages, such as ease of workup and convenient reuse of the ionic liquid, which could help reduce disposal costs and contribute to the development of new catalysts in chemical processes.

\section{Introduction}

The Knoevenagel condensation is a powerful, general, versatile and significant reaction for the formation of carbon-carbon bonds. $^{1,2}$ The classic Knoevenagel transformation ${ }^{3}$ occurs between aldehydes and active methylene hydrogen compounds, with ammonia or another amines as catalysts in organic solvents. The reaction is considered to be a modification of the aldol condensation. ${ }^{4}$

The synthesis of benzylidenes or alkylidenes, important intermediate products, via the Knoevenagel reaction is largely related to structural variations in different nucleophiles, such as 1,3-ketoesters, ${ }^{2,5}$ diketones, ${ }^{2}$ ketothioesters, ${ }^{2}$ malonates, malononitriles, ${ }^{6}$ keto amides, and cyclic esters, and with different aromatic ${ }^{7}$ or aliphatic aldehydes. ${ }^{8}$ Recently, long-chain alkylidene malonates (LoCAMs) have been identified with a novel class of KATs (protein acetyltransferase) modulators, and pentadecylidene malonate, a simplified analogue of anacardic acid, exhibits a good modulation of the activity of histone acetyltransferases (Fig. 1). ${ }^{8}$

Another example comes from the total synthesis of the anticoagulant flocoumafen. The key synthetic step involves Knoevenagel condensation with ethyl cyanoacetate and $p$ methoxybenzaldehyde in the presence of acetic acid and

\footnotetext{
${ }^{a}$ Laboratório Kolbe de Síntese Orgânica, Escola de Química e Alimentos, Universidade Federal do Rio Grande, Av. Itália Km 08 s/n, Rio Grande-RS, Brazil.E-mail:dqmdoca@ furg.br; Tel: +55 5332336964

${ }^{b}$ Laboratório de Síntese Orgânica, Instituto de Química, Universidade Federal do Rio Grande do Sul, Av. Bento Gonçalves 9500, Porto Alegre-RS, Brazil

$\dagger$ Electronic supplementary information (ESI) available: ${ }^{1} \mathrm{H}$ and ${ }^{13} \mathrm{C}$ NMR analysis for all compounds. See DOI: 10.1039/c6ra25595g
}

pyrrolidine; this process generates an excellent yield of the desired product. ${ }^{9}$

In addition, different catalytic systems (such as amines ${ }^{5}$ ), Lewis acids, and solvents (such as benzene, ${ }^{5}$ toluene, dichloromethane ${ }^{10}$ and tetrahydrofuran) have been used, and Knoevenagel condensation in ionic liquids was recently demonstrated as a strongly solvent-dependent process. ${ }^{11}$

The use of a triethylamine-toluene system in place of pyridine was shown to provide ease of handling, separation, and recycling of the solvent and the catalyst. In that case, the synthesis of cinnamic acids was successfully performed using a pyridine-free Knoevenagel condensation, either in the presence of triethylamine as a solvent or in combination with toluene with catalytic amounts of piperidine. ${ }^{12}$

Knoevenagel condensation of $\beta$-ketothioesters with various aldehydes proceeds efficiently in the presence of molecular sieves (MS 5A), and molecular sieves in $\mathrm{CH}_{2} \mathrm{Cl}_{2}$ was the most effective. The reaction was examined using several $\beta$-ketothioesters and $\beta$-ketoesters with various aromatic and aliphatic aldehydes, and the Knoevenagel adducts were obtained in

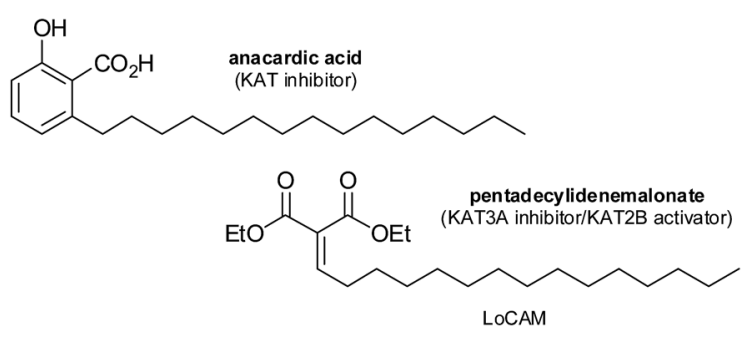

Fig. 1 KAT inhibitors and activator: anacardic acid and pentadecylidene malonate, respectively. 
yields of $20 \%$ to $95 \% .{ }^{13}$ In this work the reaction conditions were mild, and no self-condensation products of the aldehydes were observed. The amount of aldehydes can be reduced to 1.5 equiv. without affecting the yield, although a longer reaction time is necessary. The use of excessive amounts (4-6 equiv.) of aliphatic aldehydes in some cases is necessary to obtain a sufficient yield of the products in a reduced reaction time when the reaction is slow.

According to the literature,$^{14}$ a large number of $\beta$ - and $\beta, \beta$ substituted Morita-Baylis-Hillman (MBH) adducts can be synthesised using Knoevenagel condensation in piperidine and acetic acid or Lewis acid. For the synthesis of $\beta$-ketoesters, it was demonstrated that the stereoselectivity of the reaction is improved by alteration of various substituents on the ketone and ester group and various aldehydes. In addition, a Z-selective Knoevenagel condensation can be achieved by the use of tertbutyl acetoacetate with either aromatic or aliphatic aldehydes, although this results in low chemical yield.

In recent years, ionic liquids (ILs) have emerged as a greener alternative to commonly used organic solvents and catalysts. Their characteristics, combined with their low volatility, nonflammable nature, thermal stability, and capacity for reuse as catalysts, have made ILs an environmentally friendly option for organic synthesis. ${ }^{15}$ However, they are expensive (about 30000 times greater than common organic solvents); therefore, the use of inexpensive cations and anions is essential to expand their use. $^{2}$<smiles>O=CO[NH+]1CCCC1</smiles>

[Pyrr][HCOO]

PyrrlL 1<smiles>CC(=O)OC1CCCN1</smiles>
$[\mathrm{Pyr}]\left[\mathrm{CH}_{3} \mathrm{COO}\right]$

PyrrlL 2<smiles>O=C(OC1CCCN1)C(F)(F)F</smiles>

$[\mathrm{Pyr}]\left[\mathrm{CF}_{3} \mathrm{COO}\right]$

PyrrlL 3
Fig. 2 Pyrrolidinium ionic liquids (PyrrlLs) 1-3.
However, few studies have reported on the use of ILs for both their solvent and catalytic functions; ILs have been used most commonly as solvents in the presence of another catalyst/ promoter system ${ }^{16}$ or as catalysts in the presence of a solvent. ${ }^{6,17,18}$

Under ultrasonic irradiation, hexamethylenetetramine (HMTA)-AcOH- $\mathrm{H}_{2} \mathrm{O}$, a protic ionic liquid (PIL) solvent-catalyst, has been used in the Knoevenagel reaction of aromatic aldehydes with ethyl 2-cyanoacetate. However, in solvent-free conditions, the mixture solidifies as soon as the catalyst is added, making the reaction yield low. ${ }^{19}$

Anouti et al. detailed the synthesis and characterisation of ILs using pyrrolidine as the cation source and different organic and inorganic anions in an easily reproducible experimental procedure. ${ }^{20}$ They found that pyrrolidinium-based protic ILs (PyrrILs, Fig. 2) have a relatively low cost and low toxicity and exhibit a large electrochemical window compared to other protic ILs. In addition, PyrrILs are superionic liquids with wide application for fuel cell devices, thermal transfer fluids, and acid-catalysed reaction media as an alternative to conventional inorganic acids.

As part of our ongoing efforts to synthesise new fatty derivatives ${ }^{21-25}$ in this study, we describe the use of PyrrILs 1-3 derived from formate, acetate, and trifluoroacetate (Fig. 2) as a catalyst to the synthesis of long-chain alkylidenes. The Knoevenagel reaction was investigated using several classic 1,3dicarbonyl compounds ( $\beta$-ketoesters, 1,3-diketones, Meldrum's acid, and malonates) with long aldehydes in a solvent-free media.

\section{Results and discussion}

Initially, Knoevenagel condensation was investigated using the classic experimental protocol, and the catalysts pyrrolidine (Pyrr) or piperidine (Pip) and acetic acid were added directly to a reactional flask containing both 1,3-dicarbonyl compound

Table 1 Synthesis of long-chain alkylidene $6 \mathrm{~g}$ from Knoevenagel condensation

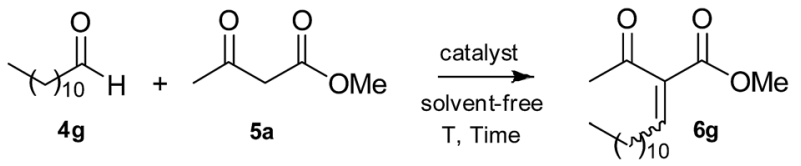

\begin{tabular}{|c|c|c|c|c|c|}
\hline Ent. & Catalyst & Loading (mol\%) & $T\left({ }^{\circ} \mathrm{C}\right)$ & Time $(\mathrm{h})$ & Yield (\%) \\
\hline 1 & Pyrr $+\mathrm{CH}_{3} \mathrm{COOH}^{a}$ & 10 & 0 & 3 & 60 \\
\hline 2 & $\mathrm{Pip}+\mathrm{CH}_{3} \mathrm{COOH}^{a}$ & 10 & 0 & 3 & 63 \\
\hline 4 & {$[\mathrm{Pyrr}]\left[\mathrm{CH}_{3} \mathrm{COO}\right], 2$} & 10 & 0 & 1.5 & 80 \\
\hline 5 & {$[\mathrm{Pyrr}]\left[\mathrm{CF}_{3} \mathrm{COO}\right], 3$} & 10 & 0 & 1.5 & 68 \\
\hline 6 & {$[\mathrm{Pyrr}]\left[\mathrm{CH}_{3} \mathrm{COO}\right], 2$} & 5 & 0 & 1.5 & 65 \\
\hline 9 & {$[\mathrm{Pyrr}]\left[\mathrm{CH}_{3} \mathrm{COO}\right], 2$} & 10 & 20 & 1.5 & 65 \\
\hline 10 & {$[\mathrm{Pip}]\left[\mathrm{CH}_{3} \mathrm{COO}\right]$ (solid catalyst) } & 10 & 0 & 1.5 & 70 \\
\hline
\end{tabular}

${ }^{a}$ Reaction performed with $\mathrm{CH}_{2} \mathrm{Cl}_{2}(2 \mathrm{~mL})$, with addition of pyrrolidine or piperidine and acetic acid directly to the reactional flask. 
Table 2 Synthesis of long-chain alkylidenes $6 \mathrm{a}-\mathrm{l}$ under catalysis with pyrrolidinium acetate (2, $\left.[\mathrm{Pyrr}]\left[\mathrm{CH}_{3} \mathrm{COO}\right]\right)$<smiles>[R7]C=C(C([R])=O)C([R])=O</smiles>

\begin{tabular}{|c|c|c|c|c|}
\hline Entry & Aldehydes (4a-g) & $5 a-e$ & Alkylidenes (6a-q) & Yield (\%), $(E: Z \text { ratio })^{a}$ \\
\hline 1 & & & & $83(1: 2)$ \\
\hline 2 & & & & $77(1: 1.8)$ \\
\hline 3 & & & & $80(1: 1.5)$ \\
\hline 4 & & & & $89(1: 2.1)$ \\
\hline 5 & & & & $72(1: 2)$ \\
\hline 6 & & & & $90(1: 2.1)$ \\
\hline 7 & & & & $80(1: 2.5)$ \\
\hline 8 & & & & 70 \\
\hline 9 & & & & 73 \\
\hline 10 & & $\mathrm{H}_{3} \mathrm{CH}_{2} \mathrm{CO}$ & & 70 \\
\hline 11 & & & & 90 \\
\hline 12 & & & & 95 \\
\hline
\end{tabular}




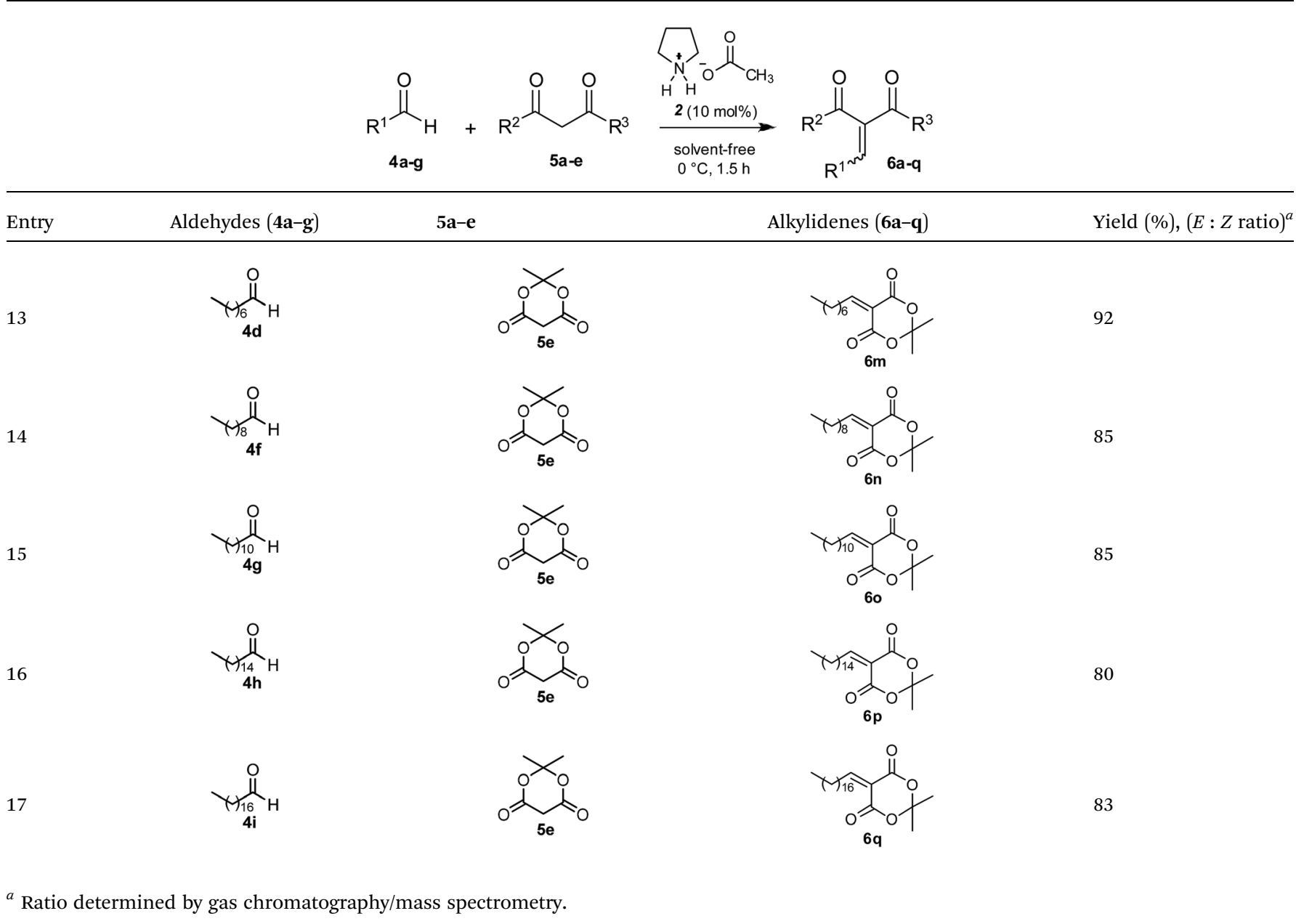

and aldehyde. ${ }^{9}$ The Knoevenagel reaction between long-chain dodecanaldehyde (4g) and methyl acetoacetate (5a) was tested with loading of $10 \mathrm{~mol} \%$ of catalyst at $0{ }^{\circ} \mathrm{C}$ and in the presence of anhydrous methylene chloride. The reactions were monitored by thin-layer chromatography (TLC), and the consumption of aldehyde was measured. However, pyrrolidine and piperidine in the presence of acetic acid each demonstrated low yields of the product $6 \mathrm{~g}$ after $3 \mathrm{~h}$. The results are shown in Table 1 , entries 1 and 2 , respectively.

Based on these results, we decided to investigate the Knoevenagel reaction employing PyrrILs 1-3 (Fig. 2).

The PyrrILs 1-3 were obtained using the same experimental protocol described by Anouti et al. ${ }^{\mathbf{2 0}}$ The nuclear magnetic resonance spectroscopic data of PyrrILs were in agreement with the literature. ${ }^{20}$ Next, the behaviour and catalytic activity of the heterogeneous PyrrILs 1-3 were initially investigated in the Knoevenagel condensation between dodecanaldehyde (49) and methyl acetoacetate (5a) using $10 \mathrm{~mol} \%$ of catalyst at $0{ }^{\circ} \mathrm{C}$ in a solvent-free condition.

The reaction using PyrrIL 1 was monitored by TLC and the total consumption of aldehyde $4 \mathrm{~g}$ was observed after $1.5 \mathrm{~h}$ at $0{ }^{\circ} \mathrm{C}$. At this point, the reaction was considered complete, and a $69 \%$ yield of product $\mathbf{6} \mathbf{g}$ was recorded (Table 1 , entry 3 ). Then
PyrrILs 2 and 3 were tested with loading of $10 \mathrm{~mol} \%$ under the same experimental conditions (Table 1, entries 4 and 5). Better catalytic behaviour was observed with pyrrolidinium acetate (2) (80\%, Table 1 , entry 4 ) than with the catalysts pyrrolidinium trifluoracetate (3) and pyrrolidinium formate (1) (Table 1, entries 5 and 3 , respectively).

The loading of catalyst 2 was then investigated, with the reactions performed with $5 \mathrm{~mol} \%$ and $20 \mathrm{~mol} \%$ (Table 1, entries 6 and 7 , respectively). The use of 5 mol\% provided a $65 \%$ yield of the product (Table 1, entry 6), while the use of $20 \mathrm{~mol} \%$ resulted in a lower yield (Table 1, entry 7). Thus, $10 \mathrm{~mol} \%$ was chosen for the Knoevenagel reactions catalysed by PyrrIL (Table 1, entry 4).

Next, we studied the influence of temperature on the reactions. In addition to performing the reactions at $0{ }^{\circ} \mathrm{C}$, the reactions were performed at $-20^{\circ} \mathrm{C}$ and $20^{\circ} \mathrm{C}$ (Table 1 , entries 8 and 9). Both temperatures resulted in lower yields than the reactions at $0{ }^{\circ} \mathrm{C}$ (Table 1 , entries $3-7$ ).

In addition, the Knoevenagel reaction employing $10 \mathrm{~mol} \%$ of piperidinium acetate ([Pip] $\left.\left[\mathrm{CH}_{3} \mathrm{COO}\right]\right)$ was investigated. The catalyst [Pip][ $\left.\mathrm{CH}_{3} \mathrm{COO}\right]$ was obtained from stoichiometric amount of piperidine and acetic acid using the same experimental protocol used for PyrrIL synthesis. The [Pip][ $\left.\mathrm{CH}_{3} \mathrm{COO}\right]$ was isolated by crystallization in dry toluene. The reaction using 
this solid catalyst [Pip] $\left[\mathrm{CH}_{3} \mathrm{COO}\right]$ was monitored by TLC and resulted in a $70 \%$ yield of the product $6 \mathrm{~g}$ (Table 1 , entry 10 ).

From these results, it was concluded that the best conditions for the Knoevenagel reaction to synthesis of long-chain alkylidene $\mathbf{6 g}$ would employ PyrrIL 2, synthesised singly, at a load of $10 \mathrm{~mol} \%$ at $0{ }^{\circ} \mathrm{C}$ (Table 1 , entry 4 ).

Thus, the Knoevenagel reaction employing PyrrIL 2 was investigated using classic 1,3-dicarbonyl compounds ( $\beta$ ketoesters, 1,3-diketones, Meldrum's acid, and malonates) with long-chain aldehydes. This same experimental protocol was used for the synthesis of long-chain alkylidenes $\mathbf{6 a - q}$ from alkyl aldehydes $\mathbf{4 a - g}$ and 1,3-dicarbonyl compounds 5a-e (Table 2).

All tested examples resulted in good to reasonable alkylidene yields (70-95\%), demonstrating the catalytic effectiveness of PyrrIL 2 in the several alkylidene syntheses. These results indicate that Knoevenagel condensation possesses catalytic versatility and efficiency, even in the presence of 1,3-dicarbonyl compounds with different $\mathrm{p} K_{\mathrm{a}}$ values, resulting in good yields of the products (Table 2, entries 7-17). As expected, good yields were observed in reactions performed with methyl acetoacetate (Table 2, entries 1-7) and lower yields were observed with ethyl malonate (70\%, Table 2, entry 10$)$. Moreover, only the enol $\mathbf{6 i}$ from aldol product was observed in reaction performed with dimedone (5c) (73\%, Table 2, entry 9). The best results were obtained when Meldrum's acid was used as the 1,3-dicarbonyl compound (80-95\%, Table 2, entries 11-17).

Based on the literature, ${ }^{19}$ a tentative mechanistic pathway of the Knoevenagel reaction to synthesis of long-chain alkylidenes catalysed by PyrrIL is proposed. We believe that the reaction may proceed through the formation of a partial oxonium ion formed from long-chain aldehyde and PyrrIL 2 (Scheme 1). The reaction

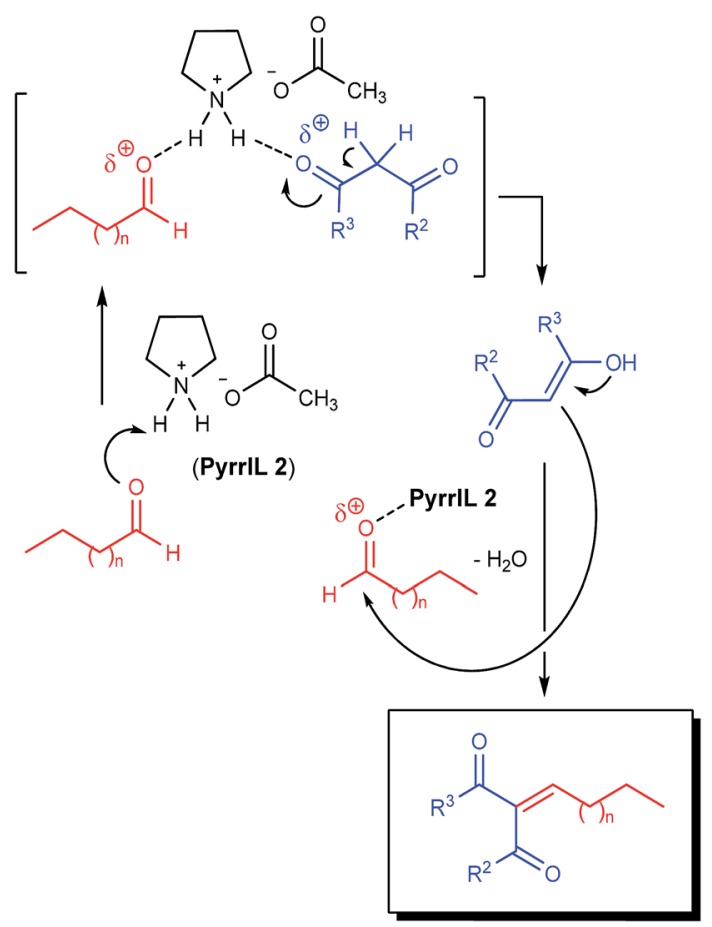

Scheme 1 The suggested pathway to the synthesis of long-chain alkylidenes via the Knoevenagel condensation catalysed by PyrrIL.

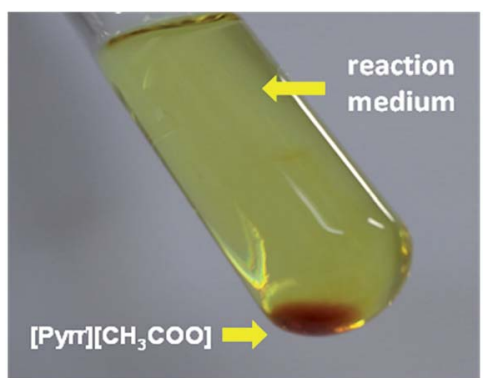

Fig. 3 Solvent-free Knoevenagel condensation catalysed by [Pyrr] $\left[\mathrm{CH}_{3} \mathrm{COO}\right](2)$

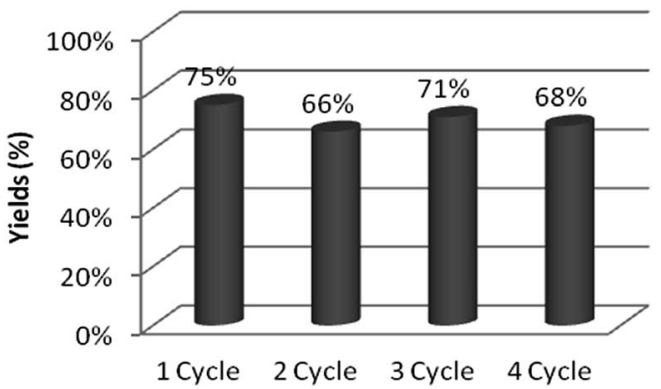

Fig. 4 Results of the recycling of catalyst PyrrIL 2 in the Knoevenagel reaction under solvent-free conditions.

of the oxonium ion, which is sufficiently electrophilic, with the enol form of 1,3-dicarbonyl compounds, together with the loss of $\mathrm{H}_{2} \mathrm{O}$, could lead to formation of the long-chain alkylidenes.

In addition, all PyrrILs tested (1-3) were insoluble in the reaction medium (Fig. 3); therefore, repeated reuse tests were performed. For this purpose, the reactions were scaled up, with the same optimised experimental conditions maintained. Repeated experiments were carried out with dodecanaldehyde (4g) and methyl acetoacetate (5a) and $10 \mathrm{~mol} \%$ of [Pyrr] $\left[\mathrm{CH}_{3} \mathrm{COO}\right](2)$ at $0{ }^{\circ} \mathrm{C}$. After each cycle, the PyrrIL 2 was decanted by centrifugation in the reactional flask, the supernatant was removed, and the process was repeated with the addition of new reagents in the reactional flask. The first reuse resulted in a slight decrease in yield. Catalytic activity was maintained well, and no decrease in the activity of PyrrIL was observed, even after the fourth reuse. The catalytic performance over four cycles is depicted in Fig. 4.

Our experiments show that the employment of PyrrILs as a catalytic system in the Knoevenagel reaction with aliphatic aldehydes and 1,3-dicarbonyl compounds resulted in good yield of alkylidenes. In addition, this technique can be performed easily, with readily available, inexpensive starting materials, and the products exhibit high stability and can be stored in air without any sign of degradation.

\section{Conclusions}

In this work, the synthesis of long-chain alkylidenes (fatty alkylidenes) was demonstrated under PyrrILs catalysis and 
solvent-free conditions. The products showed good yields (7090\%) following Knoevenagel condensation, using classic 1,3dicarbonyl compounds and long-chain aldehydes, in a few hours and using an eco-friendly approach. In addition, experiments with recycling the catalyst $[\mathrm{Pyrr}]\left[\mathrm{CH}_{3} \mathrm{COO}\right]$ make this method an attractive alternative to existing methods for the synthetically useful Knoevenagel reaction, and catalytic activity is well maintained after four cycles of catalysis.

We are in the process of synthesising a series of lipophilic $\gamma^{-}$ amino-butyric acid derivatives via long-chain $\beta$-alkyl- $\gamma$-nitroesters using fatty alkylidenes $\mathbf{6 a - q}$ as a building block.

\section{Experimental}

\section{Apparatus and chemistry}

The reagents were purchased from Aldrich Chemical Co. and used without further purification. All organic solvents used for the synthesis were of analytical grade. Column chromatography was performed using a silica gel 60 A (ACROS Organics, 0.0350.070 mesh). The reactions were monitored using thin-layer chromatography (TLC) performed with plates containing silica gel (Merck 60 GF245), and the spots were visualised using iodine. Yields refer to chromatographically and spectroscopically homogeneous materials. Infrared (IR) spectra were measured on a Shimadzu PRESTIGIE-21 FT-IR spectrophotometer. The NMR spectra were recorded using a Brucker AVANCE III 400 spectrometer $\left({ }^{1} \mathrm{H}\right.$ at $400 \mathrm{MHz}$ and ${ }^{13} \mathrm{C}$ at 100 $\mathrm{MHz}$ ) and a Varian VNMRS 300 spectrometer $\left({ }^{1} \mathrm{H}\right.$ at $300 \mathrm{MHz}$ and ${ }^{13} \mathrm{C}$ at $\left.75.5 \mathrm{MHz}\right)$ in deuterochloroform $\left(\mathrm{CDCl}_{3}\right)$ as the solvent. The chemical shift data are reported in units of $\delta(\mathrm{ppm})$ downfield from tetramethylsilane (TMS), which was used as an internal standard. The coupling constants $\left({ }^{3} J\right)$ are reported in $\mathrm{Hz}$ and refer to apparent peak multiplicities. High resolution mass spectra (HRMS) were recorded on Waters XEGO G2 Q-TOF Mass Spectrometer.

\section{Synthesis}

General procedure for the synthesis of long-chain alkylidene 6a-q. To a round-bottom flask equipped with a magnetic stirring bar were added aldehyde $\mathbf{4 a - i}(5 \mathrm{mmol})$ and 1,3-dicarbonyl 5a-e $(7.5 \mathrm{mmol})$, and the system was cooled to $0{ }^{\circ} \mathrm{C}$. Immediately, the IL [Pyrr] $\left[\mathrm{CH}_{3} \mathrm{COO}\right]$ PyrrIL 2 (10 mol\%) was added, with stirring maintained at $0{ }^{\circ} \mathrm{C}$ for $1.5 \mathrm{~h}$. The reaction was monitored by TLC with hexane : ethyl acetate ( $80: 20$ ratio) as eluent. After completion of the reaction, the raw product was purified by flash column chromatography on a silica gel, with hexane/ ethyl acetate (95:05) as eluent, to yield alkylidene $\mathbf{6 a - q}$. The purified products were analysed by proton and carbon NMR, IR, and ESI-MS/MS.

(E/Z)-Methyl-2-acetyl-4-methylpent-2-enoate (6a). Yellow oil. Yield: 83\%. IR (film, $\nu_{\max } \mathrm{cm}^{-1}$ ): 1224, 1253, 1365, 1465, 1637, 1699, 1730, 2872, 2966; ${ }^{1} \mathrm{H}$ NMR $\left(\mathrm{CDCl}_{3}, 400 \mathrm{MHz}\right): \delta 6.71$ (d, $1 \mathrm{H}, J=12.0 \mathrm{~Hz}$, isomer $E), 6.62(\mathrm{~d}, 1 \mathrm{H}, J=12.0 \mathrm{~Hz}$, isomer $Z)$, $3.83(\mathrm{~s}, 3 \mathrm{H}$, isomer $Z), 3.78(\mathrm{~s}, 3 \mathrm{H}$, isomer $E), 2.67(\mathrm{~m}, 1 \mathrm{H}$, isomers $Z, E$ ), 2.37 (s, 3H, isomer $E$ ), 2.31 (s, 3H, isomer $Z$ ), 1.09 (d, $J=8.0 \mathrm{HZ}, 6 \mathrm{H}$, isomer $Z$ ), 1.05 (d, $6 \mathrm{H}, J=4.0 \mathrm{~Hz}$, isomer $E$ ).
${ }^{13} \mathrm{C} \mathrm{NMR}\left(\mathrm{CDCl}_{3}, 100 \mathrm{MHz}\right): \delta 195.0,167.0,148.1,147.9,137.5$, 52.1, 52.0, 38.9, 38.1, 31.2, 28.3, 28.2, 26.9, 22.4, 22.3, HRMS calculated for $\mathrm{C}_{9} \mathrm{H}_{14} \mathrm{O}_{3}[\mathrm{M}-\mathrm{H}]^{-}$169.0870; found 169.0858 .

(E/Z)-Methyl 2-acetyl-5-methylhex-2-enoate (6b). Yellow oil. Yield: 77\%. IR (film, $\nu_{\max } \mathrm{cm}^{-1}$ ): 1224, 1253, 1369, 1436, 1637, 1701, 1726, 2872, 2958; ${ }^{1} \mathrm{H} \mathrm{NMR}\left(\mathrm{CDCl}_{3}, 400 \mathrm{MHz}\right): \delta 6.95(\mathrm{t}, 1 \mathrm{H}$, $J=8.0 \mathrm{~Hz}$, isomer $E$ ), $6.88(\mathrm{t}, 1 \mathrm{H}, J=8.0 \mathrm{~Hz}$, isomer $Z), 3.84(\mathrm{~s}$, $3 \mathrm{H}$, isomer $Z$ ), $3.79(\mathrm{~s}, 3 \mathrm{H}$, isomer $E$ ), 2.36 (s, 3H, isomer $E$ ), 2.32 $(\mathrm{s}, 3 \mathrm{H}$, isomer $Z$ ), $2.21(\mathrm{t}, 2 \mathrm{H}, J=8.0 \mathrm{~Hz}$, isomer $Z), 2.15(\mathrm{t}, 2 \mathrm{H}, J$ $=8.0 \mathrm{~Hz}$, isomer $E), 1.82(\mathrm{~m}, 1 \mathrm{H}$, isomer $Z, E), 0.96-0.93(\mathrm{~m}, 6 \mathrm{H}$, isomer $E, Z) .{ }^{13} \mathrm{C} \mathrm{NMR}\left(\mathrm{CDCl}_{3}, 100 \mathrm{MHz}\right): \delta 195.0,167.0,148.1$, 147.9, 137.5, 52.1, 52.0, 38.9, 38.2, 31.2, 28.3, 28.2, 26.9, 22.4, 22.4. HRMS calculated for $\mathrm{C}_{10} \mathrm{H}_{16} \mathrm{O}_{3}[\mathrm{M}-\mathrm{H}]^{-}$183.1032; found 183.1029 .

(E/Z)-Methyl 2-acetyloct-2-enoate (6c). Yellow oil. Yield: $80 \%$. IR (film, $\nu_{\max } \mathrm{cm}^{-1}$ ): 1240, 1251, 1379, 1462, 1637, 1722, 2860, 2956; ${ }^{1} \mathrm{H} \mathrm{NMR}\left(\mathrm{CDCl}_{3}, 400 \mathrm{MHz}\right): \delta 6.94(\mathrm{t}, 1 \mathrm{H}, J=8.0 \mathrm{~Hz}$, isomer $E$ ), $6.87(\mathrm{t}, 1 \mathrm{H}, J=8.0 \mathrm{~Hz}$, isomer $Z), 3.83(\mathrm{~s}, 3 \mathrm{H}$, isomer $Z), 3.79(\mathrm{~s}, 3 \mathrm{H}$, isomer $E), 2.37(\mathrm{~s}, 3 \mathrm{H}$, isomer $E), 2.32(\mathrm{~s}, 3 \mathrm{H}$, isomer $Z)$, 1.57-1.44 (m, 2H, isomer $Z, E), 1.38-1.22(\mathrm{~m}, 6 \mathrm{H}$, isomer $E, Z), 0.93(\mathrm{~m}, 8 \mathrm{H}$, isomer $E, Z) .{ }^{13} \mathrm{C} \mathrm{NMR}\left(\mathrm{CDCl}_{3}, 100\right.$ $\mathrm{MHz}): \delta 195.2,167.0,149.5,149.2,137.7,136.9,52.1,52.1,31.4$, $30.1,29.2,28.1,26.9,22.4,22.4,13.9$. HRMS calculated for $\mathrm{C}_{11} \mathrm{H}_{18} \mathrm{O}_{3}[\mathrm{M}-\mathrm{H}]^{-}$197.1172; found 197.1174.

(E/Z)-Methyl 2-acetyldec-2-enoate (6d). Yellow oil. Yield: 89\%. IR (film, $\nu_{\max } \mathrm{cm}^{-1}$ ): 1247, 1253, 1365, 1436, 1637, 1714, 2856, 2954; ${ }^{1} \mathrm{H} \mathrm{NMR}\left(\mathrm{CDCl}_{3}, 400 \mathrm{MHz}\right): \delta 6.95(\mathrm{t}, 1 \mathrm{H}, J=8.0 \mathrm{~Hz}$, isomer $E$ ), $6.88(\mathrm{t}, 1 \mathrm{H}, J=8.0 \mathrm{~Hz}$, isomer $Z), 3.85(\mathrm{~s}, 3 \mathrm{H}$, isomer $Z$ ), $3.80(\mathrm{~s}, 3 \mathrm{H}$, isomer $E), 2.38(\mathrm{~m}, 8 \mathrm{H}$, isomer $E, Z), 1.57-1.44$ $(\mathrm{m}, 2 \mathrm{H}$, isomer $Z, E), 1.38-1.22$ (m, 8H, isomer $E, Z), 0.93-0.86$ (m, 3H, isomer $E, Z) .{ }^{13} \mathrm{C} \mathrm{NMR}\left(\mathrm{CDCl}_{3}, 100 \mathrm{MHz}\right): \delta 195.2,166.9$, 149.4, 149.2, 136.9, 52.0, 31.7, 30.1, 29.4, 29.2, 28.9, 28.6, 28.4, 26.8, 22.6, 14.0. HRMS calculated for $\mathrm{C}_{13} \mathrm{H}_{22} \mathrm{O}_{3}[\mathrm{M}+\mathrm{H}]^{+}$ 225.1485; found 225.1488 .

(Z)-Methyl 2-acetylundec-2-enoate (6e). Yellow oil. Yield: $72 \%$. IR (film, $\nu_{\max } \mathrm{cm}^{-1}$ ): 1226, 1381, 1438, 1637, 1726, 2856, 2954; ${ }^{1} \mathrm{H} \mathrm{NMR}\left(\mathrm{CDCl}_{3}, 400 \mathrm{MHz}\right): \delta 6.95(\mathrm{t}, 1 \mathrm{H}, J=8.0 \mathrm{~Hz}$, isomer $E)$, $6.88(\mathrm{t}, 1 \mathrm{H}, J=8.0 \mathrm{~Hz}$, isomer $Z), 3.85(\mathrm{~s}, 3 \mathrm{H}$, isomer $Z), 3.80(\mathrm{~s}$, $3 \mathrm{H}$, isomer $E), 2.38-2.23(\mathrm{~m}, 8 \mathrm{H}$, isomer $E, Z), 1.51(\mathrm{~m}, 2 \mathrm{H}$, isomer $E, Z), 1.28(\mathrm{~m}, 10 \mathrm{H}$, isomer $E, Z), 0.91-0.87(\mathrm{~m}, 3 \mathrm{H}$, isomer $E, Z) .{ }^{13} \mathrm{C} \mathrm{NMR}\left(\mathrm{CDCl}_{3}, 100 \mathrm{MHz}\right): \delta 195.2,167.0,149.2$, 136.9, 52.1, 31.8, 30.1, 29.4, 29.3, 28.4, 26.9, 22.7, 14.1. HRMS calculated for $\mathrm{C}_{14} \mathrm{H}_{24} \mathrm{O}_{3}[\mathrm{M}-\mathrm{H}]^{-}$239.1653; found 239.1660.

(E/Z)-Methyl 2-acetyldodec-2-enoate (6f). Yellow oil. Yield: 90\%. IR (film, $\nu_{\text {max }} \mathrm{cm}^{-1}$ ): 1220, 1361, 1381, 1462, 1635, 1695, 1730, 2854, 2927; ${ }^{1} \mathrm{H}$ NMR $\left(\mathrm{CDCl}_{3}, 400 \mathrm{MHz}\right): \delta 6.93(\mathrm{t}, 1 \mathrm{H}, J=$ $8.0 \mathrm{~Hz}$, isomer $E$ ), $6.85(\mathrm{t}, 1 \mathrm{H}, J=4.0 \mathrm{~Hz}$, isomer $Z), 3.76(\mathrm{~s}, 3 \mathrm{H}$, isomer $Z$ ), 3.71 (s, $3 \mathrm{H}$, isomer $E$ ), 2.29-2.15 (m, $8 \mathrm{H}$, isomer $E, Z$ ), $1.41(\mathrm{~m}, 2 \mathrm{H}$, isomer $E, Z), 1.22(\mathrm{~m}, 12 \mathrm{H}$, isomer $E, Z), 0.81(\mathrm{t}, 3 \mathrm{H}$, $J=8.0 \mathrm{~Hz}$, isomer $E, Z) .{ }^{13} \mathrm{C} \mathrm{NMR}\left(\mathrm{CDCl}_{3}, 100 \mathrm{MHz}\right): \delta 195.1$, 166.9, 165.0, 149.4, 149.2, 137.7, 136.8, 135.2, 63.6, 52.4, 52.0, 32.5 , 31.8, 31.2, 29.4, 29.1, 28.6, 29.2, 28.8, 26.8, 22.6, 14.1. HRMS calculated for $\mathrm{C}_{15} \mathrm{H}_{26} \mathrm{O}_{3}[\mathrm{M}-\mathrm{H}]^{-}$253.1709; found 253.1812.

(E/Z)-Methyl 2-acetyltetradec-2-enoate (6g). Yellow oil. Yield: $80 \%$. IR (film, $\nu_{\max } \mathrm{cm}^{-1}$ ): 1219, 1361, 1379, 1463, 1637, 1697, 1730, 2854, 2926; ${ }^{1} \mathrm{H}$ NMR $\left(\mathrm{CDCl}_{3}, 400 \mathrm{MHz}\right): \delta 6.94(\mathrm{t}, 1 \mathrm{H}, J=$ 
$8.0 \mathrm{~Hz}$, isomer $E), 6.86(\mathrm{t}, 1 \mathrm{H}, J=8.0 \mathrm{~Hz}$, isomer $Z), 3.83(\mathrm{~s}, 3 \mathrm{H}$, isomer $Z$ ), 3.78 (s, $3 \mathrm{H}$, isomer $E$ ), 2.37-2.22 (m, $8 \mathrm{H}$, isomer $E, Z)$, 1.53-1.40 (m, 2H, isomer $Z, E), 1.26$ (m, 16H, isomer $E, Z), 0.88$ (t, 3H, $J=8.0 \mathrm{~Hz}$, isomer $E, Z) .{ }^{13} \mathrm{C} \mathrm{NMR}\left(\mathrm{CDCl}_{3}, 100 \mathrm{MHz}\right)$ : $\delta$ 195.2, 166.9, 149.2, 137.8, 136.8, 135.2, 63.6, 52.0, 33.4, 31.9, 31.2, 30.1, 28.4, 28.6, 26.9, 19.9, 14.1. HRMS calculated for $\mathrm{C}_{17} \mathrm{H}_{30} \mathrm{O}_{3}[\mathrm{M}+\mathrm{H}]^{+}$283.2268; found 283.2270.

3-Dodecylidenepentane-2,4-dione (6h). Yellow oil. Yield: $70 \%$. ${ }^{1} \mathrm{H} \mathrm{NMR}\left(\mathrm{CDCl}_{3}, 400 \mathrm{MHz}\right): \delta 6.68(\mathrm{t}, 1 \mathrm{H}, J=8.0 \mathrm{~Hz}), 2.32(\mathrm{~s}, 3 \mathrm{H})$, $2.23(\mathrm{q}, 2 \mathrm{H}, J=8.0 \mathrm{~Hz}), 1.48(\mathrm{~m}, 2 \mathrm{H}), 1.26(\mathrm{~s}, 16 \mathrm{H}), 0.88(\mathrm{t}, 3 \mathrm{H}, J$ $=8.0 \mathrm{~Hz}) \cdot{ }^{13} \mathrm{C} \mathrm{NMR}\left(\mathrm{CDCl}_{3}, 100 \mathrm{MHz}\right): \delta 203.5,190.8,197.1$, 146.9, 145.2 , 137.3, 123.5, 33.0, 31.9, 31.7, 29.6, 29.3, 28.9, 28.7, 26.0, 24.0, 22.7, 14.1. HRMS calculated for $\mathrm{C}_{17} \mathrm{H}_{30} \mathrm{O}_{2}[\mathrm{M}-\mathrm{H}]^{-}$ 265.2173; found 265.2161.

3-Hydroxy-2-(1-hydroxydodecyl)-5,5-dimethylcyclohex-2-enone (6i). White solid. Yield: $73 \% .{ }^{1} \mathrm{H}$ NMR $\left(\mathrm{CDCl}_{3}, 400 \mathrm{MHz}\right): \delta 12.48(\mathrm{~s}$, $1 \mathrm{H}), 3.91(\mathrm{t}, 1 \mathrm{H}, J=8.0 \mathrm{~Hz}), 2.34-2.23(\mathrm{~m}, 4 \mathrm{H}), 2.00(\mathrm{~m}, 2 \mathrm{H}), 1.22$ $(\mathrm{m}, 18 \mathrm{H}), 1.07(\mathrm{~s}, 3 \mathrm{H}), 1.06(\mathrm{~s}, 3 \mathrm{H}), 0.88(\mathrm{t}, 3 \mathrm{H}, J=8.0 \mathrm{~Hz}) .{ }^{13} \mathrm{C} \mathrm{NMR}$ $\left(\mathrm{CDCl}_{3}, 100 \mathrm{MHz}\right): \delta$ 189.9, 189.5, 116.6, 47.0, 46.2, 31.9, 31.1, 29.9, 29.6, 29.5, 29.3, 29.3, 29.1, 29.0, 26.7, 22.6, 14.1. HRMS calculated for $\mathrm{C}_{20} \mathrm{H}_{36} \mathrm{O}_{3}[\mathrm{M}+\mathrm{H}]^{+}$325.2698; found 325.2786.

Diethyl 2-dodecylidenemalonate (6j). Yellow oil. Yield: $70 \% .{ }^{1} \mathrm{H}$ $\operatorname{NMR}\left(\mathrm{CDCl}_{3}, 400 \mathrm{MHz}\right): \delta 6.92(\mathrm{t}, 1 \mathrm{H}, J=8.0 \mathrm{~Hz}), 4.23(\mathrm{q}, 2 \mathrm{H}, J=$ $7.0 \mathrm{~Hz}), 4.16(\mathrm{q}, 2 \mathrm{H}, J=7.0 \mathrm{~Hz}), 2.21(\mathrm{~m}, 2 \mathrm{H}), 1.22(\mathrm{~m}, 24 \mathrm{H}), 0.81$ $(\mathrm{t}, 3 \mathrm{H}, J=6.85 \mathrm{~Hz}) .{ }^{13} \mathrm{C} \mathrm{NMR}\left(\mathrm{CDCl}_{3}, 100 \mathrm{MHz}\right): \delta$ 165.6, 164.1, 149.6, 128.6, 61.2, 31.9, 29.7, 29.6, 28.3, 22.7, 14.1. HRMS calculated for $\mathrm{C}_{19} \mathrm{H}_{34} \mathrm{O}_{4}[\mathrm{M}+\mathrm{H}]^{+} 327.2530$; found 327.2551 .

2,2-Dimethyl-5-(3-methylbutylidene)-1,3-dioxane-4,6-dione (6k).. ${ }^{26}$ Yellow oil. Yield: $90 \%$. IR (film, $\nu_{\max } \mathrm{cm}^{-1}$ ): 3479, 3004, 2956, 2860, 1789, 1733, 1637, 1476, 1286, 1202, 1001, 912, 799; ${ }^{1} \mathrm{H}$ NMR $\left(300 \mathrm{MHz}, \mathrm{CDCl}_{3}\right): \delta 7.96(\mathrm{t}, 1 \mathrm{H}, J=7.5 \mathrm{~Hz}), 2.86(\mathrm{t}, 2 \mathrm{H}$, $J=7.5 \mathrm{~Hz}$ ), 1.96 (sept, $1 \mathrm{H}, J=7.5 \mathrm{~Hz}$ ), 1.75 (s, 6H), 1.01 (d, 6H, $=6.0 \mathrm{~Hz}) .{ }^{13} \mathrm{C} \mathrm{NMR}\left(75 \mathrm{MHz}, \mathrm{CDCl}_{3}\right): \delta 167.9,161.8,159.8$, 118.6, 104.8, 39.7, 28.6, 27.6 (2C), 22.5 (2C).

5-Hexylidene-2,2-dimethyl-1,3-dioxane-4,6-dione (6l). Yellow oil. Yield: 95\%. IR (film, $\nu_{\max } \mathrm{cm}^{-1}$ ): 3446, 3009, 2936, 2855, 1795, 1746, 1624, 1560, 1357, 1301, 1195, 1017, 928, 799; ${ }^{1} \mathrm{H}$ $\operatorname{NMR}\left(300 \mathrm{MHz}, \mathrm{CDCl}_{3}\right): \delta 7.95(\mathrm{t}, 1 \mathrm{H}, J=7.5 \mathrm{~Hz}), 2.96(\mathrm{q}, 2 \mathrm{H}, J=$ $7.5 \mathrm{~Hz}), 1.76(\mathrm{~s}, 6 \mathrm{H}), 1.62(\mathrm{~m}, 2 \mathrm{H}), 1.38(\mathrm{~m}, 4 \mathrm{H}), 0.92(\mathrm{t}, 3 \mathrm{H}, J=$ $6.0 \mathrm{~Hz}) .{ }^{13} \mathrm{C} \mathrm{NMR}\left(75 \mathrm{MHz}, \mathrm{CDCl}_{3}\right): \delta 169.6,165.6,162.5,160.4$, 118.6, 105.4, 32.3, 31.7, 29.5, 28.3, 23.2, 14.7. HRMS calculated for $\mathrm{C}_{12} \mathrm{H}_{18} \mathrm{O}_{4}[\mathrm{M}-\mathrm{H}]^{-}$225.1132; found 225.1124.

2,2-Dimethyl-5-octylidene-1,3-dioxane-4,6-dione (6m). Yellow oil. Yield: 92\%. IR (film, $\nu_{\max } \mathrm{cm}^{-1}$ ): 3446, 3009, 2936, 2855, $1795,1746,1624,1560,1357,1301,1195,1017,928,799 ;{ }^{1} \mathrm{H}$ NMR (300 MHz, $\left.\mathrm{CDCl}_{3}\right): \delta 0.90(\mathrm{t}, 3 \mathrm{H}, J=6.0 \mathrm{~Hz}), 1.30(\mathrm{~m}, 10 \mathrm{H})$, 1.61 (quint, $2 \mathrm{H}, J=6.0 \mathrm{~Hz}), 1.76(\mathrm{~s}, 6 \mathrm{H}), 2.96(\mathrm{q}, 2 \mathrm{H}, J=6.0 \mathrm{~Hz})$, $7.95(\mathrm{t}, 1 \mathrm{H}, J=6.0 \mathrm{~Hz}) .{ }^{13} \mathrm{C} \mathrm{NMR}\left(75 \mathrm{MHz}, \mathrm{CDCl}_{3}\right): \delta 14.7,23.2$, 28.3, 28.8, 29.6, 30.0, 31.8, 32.3, 105.4, 118.7, 160.5, 162.5, 165.6, 169.7. HRMS calculated for $\mathrm{C}_{14} \mathrm{H}_{22} \mathrm{O}_{4}[\mathrm{M}-\mathrm{H}]^{-}$253.1445; found 253.1439.

5-Decylidene-2,2-dimethyl-1,3-dioxane-4,6-dione (6n). Yellow pale paste solid. Yield: $85 \%$. IR (film, $\nu_{\max } \mathrm{cm}^{-1}$ ): 3009, 2928, 2847, 1792, 1752, 1738, 1639, 1467, 1381, 1296, 1201, 1002, 925, 799. ${ }^{1} \mathrm{H}$ NMR (300 MHz, $\left.\mathrm{CDCl}_{3}\right): \delta 7.93(\mathrm{t}, 1 \mathrm{H}, J=7.5 \mathrm{~Hz}), 2.94$ $(\mathrm{q}, 2 \mathrm{H}, J=9.0 \mathrm{~Hz}), 1.74(\mathrm{~s}, 6 \mathrm{H}), 1.59(\mathrm{~m}, 2 \mathrm{H}), 1.26(\mathrm{~m}, 10 \mathrm{H}), 0.88$ $(\mathrm{t}, 3 \mathrm{H}, J=6.0 \mathrm{~Hz}) .{ }^{13} \mathrm{C} \mathrm{NMR}\left(75 \mathrm{MHz}, \mathrm{CDCl}_{3}\right): \delta 169.7,162.6$,
$160.5,118.7,105.5,32.5,31.8,30.1,30.0,29.9,28.9,28.8,28.3$ (2C), 23.3, 14.7. HRMS calculated for $\mathrm{C}_{16} \mathrm{H}_{26} \mathrm{O}_{4}[\mathrm{M}-\mathrm{H}]^{-}$ 281.1758; found 281.1749.

5-Dodecylidene-2,2-dimethyl-1,3-dioxane-4,6-dione (6o). White solid, mp 67-69 ${ }^{\circ} \mathrm{C}$. Yield: $85 \%$. IR (film, $\nu_{\max } \mathrm{cm}^{-1}$ ): 3398, 3009, 2920, 2847, 1802, 1748, 1738, 1641, 1568, 1462, 1381, 1309, 1203, 1009, 912, 807, 718. ${ }^{1} \mathrm{H}$ NMR $\left(\mathrm{CDCl}_{3}, 300 \mathrm{MHz}\right): \delta 7.96(\mathrm{t}$, $1 \mathrm{H}, J=7.2 \mathrm{~Hz}), 2.96(\mathrm{~m}, 2 \mathrm{H}), 1.76(\mathrm{~s}, 6 \mathrm{H}), 1.62(\mathrm{~m}, 2 \mathrm{H}), 1.28(\mathrm{~m}$, $16 \mathrm{H}), 0.91(\mathrm{t}, 3 \mathrm{H}, J=7.0 \mathrm{~Hz}) .{ }^{13} \mathrm{C} \mathrm{NMR}\left(\mathrm{CDCl}_{3}, 75 \mathrm{MHz}\right): \delta 169.7$, 162.2, 160.5, 118.7, 105.4, 32.5, 31.8, 31.6, 30.2 (2C), 30.1 (2C), 29.2 (2C), 28.8, 28.3, 23.3, 14.7. HRMS calculated for $\mathrm{C}_{18} \mathrm{H}_{30} \mathrm{O}_{4}$ $[\mathrm{M}-\mathrm{H}]^{-}$309.2071; found 309.2061.

5-Hexadecylidene-2,2-dimethyl-1,3-dioxane-4,6-dione (6p). White solid, mp 81-83 ${ }^{\circ} \mathrm{C}$. Yield: $80 \%$. IR (film, $\nu_{\max } \mathrm{cm}^{-1}$ ): 3001, 2920, 2855, 1795, 1746, 1730, 1641, 1462, 1381, 1301, 1195, 1001, 799, 718. ${ }^{1} \mathrm{H}$ NMR (300 MHz, $\left.\mathrm{CDCl}_{3}\right): \delta 7.93(\mathrm{t}, 1 \mathrm{H}, J=7.5 \mathrm{~Hz}), 2.94(\mathrm{q}$, $2 \mathrm{H}, J=6.0 \mathrm{~Hz}), 1.74(\mathrm{~s}, 6 \mathrm{H}), 1.60(\mathrm{~m}, 2 \mathrm{H}), 1.28(\mathrm{~m}, 24 \mathrm{H}), 0.88(\mathrm{t}$, $3 \mathrm{H}, J=6.0 \mathrm{~Hz}) .{ }^{13} \mathrm{C} \mathrm{NMR}\left(75 \mathrm{MHz}, \mathrm{CDCl}_{3}\right): \delta 169.0,161.9,159.8$, 118.0, 104.7, 31.9, 31.1, 29.6 (4C), 29.5 (2C), 29.4 (2C), 29.3 (2C), 29.2, 28.1, 27.6 (2C), 14.0. HRMS calculated for $\mathrm{C}_{22} \mathrm{H}_{38} \mathrm{O}_{4}[\mathrm{M}-$ $\mathrm{H}]^{-}$365.2697; found 365.2690.

2,2-Dimethyl-5-octadecylidene-1,3-dioxane-4,6-dione (6q). White solid, mp 78-79 ${ }^{\circ} \mathrm{C}$. Yield 83\%. IR (film, $\nu_{\max } \mathrm{cm}^{-1}$ ): 3001, 2920, 2847, 1786, 1738, 1624, 1471, 1390, 1293, 1195, 1009, 799, 718. ${ }^{1} \mathrm{H}$ $\operatorname{NMR}\left(300 \mathrm{MHz}, \mathrm{CDCl}_{3}\right): \delta 7.95(\mathrm{t}, 1 \mathrm{H}, J=7.5 \mathrm{~Hz}), 2.95(\mathrm{q}, 2 \mathrm{H}, J=$ $6.0 \mathrm{~Hz}), 1.76(\mathrm{~s}, 6 \mathrm{H}), 1.61(\mathrm{~m}, 2 \mathrm{H}), 1.27(\mathrm{~m}, 28 \mathrm{H}), 0.90(\mathrm{t}, 3 \mathrm{H}, J=$ $7.5 \mathrm{~Hz}) .{ }^{13} \mathrm{C} \mathrm{NMR}\left(75 \mathrm{MHz}, \mathrm{CDCl}_{3}\right): \delta$ 168.5, 161.4, 159.3, 117.5, 104.3, 31.4, 30.7, 29.2 (4C), 29.1 (2C), 29.0 (2C), 28.9 (2C), 28.8 (2C), 27.7, 27.2 (2C), 22.4, 13.6. HRMS calculated for $\mathrm{C}_{24} \mathrm{H}_{42} \mathrm{O}_{4}[\mathrm{M}$ $-\mathrm{H}]^{-}$393.3010; found 393.2995.

\section{Acknowledgements}

The authors are grateful for the financial support of Coordenação de Aperfeiçoamento de Pessoal de Nível Superior (CAPES), Fundação de Apoio à Pesquisa do Estado do Rio Grande do Sul (FAPERGS/PRONEM), and Conselho Nacional de Desenvolvimento Científico e Tecnológico (CNPq). Fellowships from CAPES and CNPq (D. Russowsky and M. G. Montes D'Oca) are also acknowledged.

\section{Notes and references}

1 Y. Hayashi, Y. Miyamoto and M. Shoji, Tetrahedron Lett., 2002, 43, 4079.

2 R. Tanikaga, N. Konya, K. Hamamura and A. Kaji, Bull. Chem. Soc. Jpn., 1988, 61, 3211.

3 E. Knoevenagel, Ber. Dtsch. Chem. Ges., 1894, 27, 2345.

4 R. Menegatti, in Green Chemistry - Environmentally Benign Approaches, ed. M. Kidwai and N. K. Mishra, InTech, Rijeka, 2012, ch. 2, pp. 13-32.

5 R. Antonioletti, P. Bovicelli and S. Malancona, Tetrahedron, 2002, 58, 589.

6 D. C. Forbes, A. M. Law and D. W. Morrison, Tetrahedron Lett., 2006, 47, 1699.

7 T. Sakai, K. Miyata, S. Tsuboi and M. Utaka, Bull. Chem. Soc. Jpn., 1989, 62, 4072. 
8 C. Milite, S. Castellano, R. Benedetti, A. Tosco, C. Ciliberti, C. Vicidomini, L. Boully, G. Franci, L. Altucci, A. Mai and G. Sbardella, Bioorg. Med. Chem., 2011, 19, 3690.

9 J.-C. Jung, E. Lim, Y. Lee, D. Min, J. Ricci, O.-S. Park and M. Jung, Molecules, 2012, 17, 2091.

10 G. Papori and D. Babulal, Tetrahedron Lett., 2009, 50, 897.

11 E. Priede, S. Brica, E. Bakis, N. Udris and A. Zicmanis, New J. Chem., 2015, 39, 9132.

12 H. S. Pawar, A. S. Wagh and A. M. Lali, New J. Chem., 2016, 40, 4962.

13 H. Yujiro, M. Yuji and S. Mitsuru, Tetrahedron Lett., 2002, 43, 4079.

14 D. I. Magee, S. Ratshonka, J. McConaghy and M. Hood, Can. J. Chem., 2012, 90, 450.

15 S. Keskin, D. Kayrak-Talay, U. Akman and O. Hortaçsu, J. Supercrit. Fluids, 2007, 43, 150.

16 S. Balalaie, A. Poursaeed, M. J. Khoshkholgh, H. R. Bijanzadeh and E. Wolf, C. R. Chim., 2012, 15, 283.

17 F. A. Khan, J. Dash, R. Satapathy and S. K. Upadhyay, Tetrahedron Lett., 2004, 45, 3055.

18 D. W. Morrison, D. C. Forbes and J. H. Davis Jr, Tetrahedron Lett., 2001, 42, 6053.

19 S. Zhao, X. Wang and L. Zang, RSC Adv., 2013, 3, 11691.
20 M. Anouti, M. Caillon-Caravanier, Y. Dridi, H. Galiano and D. Lemordant, J. Phys. Chem. B, 2008, 112, 13335.

21 T. G. M. Treptow, F. Figueiró, E. H. F. Jandrey, A. M. O. Battastini, C. G. Salbego, J. B. Hoppe, P. S. Taborda, S. B. Rosa, L. A. Piovesan, C. R. M. D'Oca, D. Russowsky and M. G. M. D'Oca, Eur. J. Med. Chem., 2015, 95, 552.

22 C. R. M. D'Oca, T. Coelho, T. G. Marinho, C. R. L. Hack, R. D. Duarte, P. A. da Silva and M. G. M. D'Oca, Bioorg. Med. Chem. Lett., 2010, 20, 5255.

23 R. D. Duarte, R. Ongaratto, L. A. Piovesan, V. R. de Lima, V. Soldi, A. A. Merlo and M. G. M. D'Oca, Tetrahedron Lett., 2012, 53, 2454.

24 D. S. dos Santos, L. A. Piovesan, C. R. M. D'Oca, C. R. L. Hack, T. G. M. Treptow, M. O. Rodrigues, D. B. Vendramini-Costa, A. L. T. G. Ruiz, J. E. de Carvalho and M. G. M. D'Oca, Bioorg. Med. Chem., 2015, 23, 340.

25 R. C. Brinkerhoff, H. F. Tarazona, P. M. de Oliveira, D. C. Flores, C. R. M. D'Oca, D. Russowsky and M. G. M. D'Oca, RSC Adv., 2014, 4, 49556.

26 O. Bassas, J. Huuskonen, K. Rissanen and A. M. P. Koskinen, Eur. J. Org. Chem., 2009, 1340. 